\title{
ANNOTATED LIST OF THE DESCRIBED SPECIES OF PARASITIC COPEPODA (SIPHONOSTOMA) FROM AMERICAN WATERS CON- TAINED IN THE UNITED STATES NATIONAL MUSEUM.
}

\section{BY RICHA RE RATHAUN.}

The collection of marine invertebrates in the U. S. National Museum contains a large number of species of parasitic Copepoda, which have been mostly obtained from the New England coast during recent years by the U. S. Fish Commission. Of these the writer has identified twenty-six species (two doubtfully) with species already described by European and American writers, as recorded in the present list. Seventeen are identical with European forms, and it is probable that further studies will increase the number of species common to both sides of the Atlantic. In many of these determinations he has had the opportunity of making direct comparisons with European specimens received in exchange from the Rev. A. M. Norman and Prof. G. S. Brady, of England.

Two species of Argulus (A. laticauda and A. megalops) described by Prof. S. I. Smith, in 1873, from specimens taken at the surface and among algæ, have been located on several species of fish, and two Atlantic species (Lepeophtheirus salmonis and Anchorella uncinata) have been traced to the Alaskan region. Three of the species recorded in the list (Argulus alose (?), Anthosoma crassum, and Cecrops Latreillii) were mentioned by Gould in his "Report on the Invertebrata of Massachusetts," 1841; and ten species of the same (Caligus curtus, Caligus rapax, Echthrogaleus coleoptratus, Pandarus Cranchii (?), Nogagus Latreillii, Cecrops Latreillii, Anthosoma crassum, Lerncea branchialis, Anchorella uncinata, and Lerncenema radiata) are given by Professor Smith, from personal observation, in the "Report of the U.S. Commissioner of" Fish and Fisheries," Part I, for 1871 (1873). In the same report Professor Smith describes four new species, which are also here includedArgulus laticauda, Argulus latus, Argulus megalops, and Echthrogaleus denticulatus. The following additional species recorded by him, mostly on the authority of others, are not contained in the museum collection, and have not been observed by the writer: Ergasilus labracis (Kröyer), Argulus catostomi (Dana and Herrick), Nogagus tenax (Steenstrup and Liitken), and Pandarus sinuatus (Say). The Pennella, of which there are many specimens in the museum collection, have not yet been studied.

The numbers which precede the localities in the list and those included in parentheses in the notes refer to the Crustacean catalogue of the U.S. National Museum. The number of specimens in each lot is also stated, being given at the end of each entry. The bibliographical references have been mainly restricted to the authority for the species and to the American publicatious treating of the same. The classifica- 
tion followed is that proposed by Dr. C. Heller in his report on the Crustacea of the Novara exploring expedition. Mr. V. N. Edwards, whose name frequently appears in the following list, is a collector in the service of the U. S. Fish Commission at Wood's Holl, Mass., and has contributed much material in this group of animals.

\section{Argulus laticauda, Smith.}

\section{ARGULINA.}

Report U. S. Commissioner of Fish and Fisheries, part i, p. 574 (280), 1873. From the Eel, Anguilla rostrata, (Le S.) De Kay :

6177. Noank, Conn., U. S. Fish Commission, 1874; 14 specimens.

6013. Wood's Holl, Mass., V. N. Edwards, October 27, 1881 ; 34 specimens.

$6014,6015,6016$. Wood's Holl, Mass., V. N. Edwards, October 27, 1881 ; 3 specimens. (Microscopic preparations.)

8278, 8279. Wood's Holl, Mass., V. N. Edwards, October 19, 23, $1883 ; 12+$ 6 specimens.

From the New England Flat Fish, Pleuronectes americanus, Walb. :

6152. Waquoit Harbor, Falmouth, Mass., U. S. Fish Commission, September 10,$1883 ; 3$ specimens.

6171. Waquoit Harbor, Falmouth, Mass., U. S. Fish Commission, September 26,1883 ; 1 specimen.

\section{Host unknown :}

6054. Buzzard's Bay, Massachusetts, U. S. Fish Commission, August 14, 1883 ; 1 specimen.

From among algee :

6182. Vineyard Sound, Massachusetts, U. S. Fish Commission, August, 1871; 2 specimens. ('Types of $\mathrm{S}$. I. Smith.)

This species has so far proved to be the most abundant one of the genus on the southern coast of New England, although the Argulus megalops is more widely distributed as regards the different species of fish on which it has been found. Its eommon host is the eel. Mr. V. N. Edwards, of Wood's Holl, who has often observed it, states that specimens of this fish are frequently infested by it to an extraordinary extent, and he estimates that as many as a hundred parasites are occasionally found on a single individual. The original specimens described by Professor Smith were found among algæ from the shore and at the surface. The largest of his specimens is somewhat below the average size of those obtained from eels, but otherwise they are charac. teristic. This species is readily distinguished from the other described New England species by its black markings, which generally cover the greater part of the body.

Argulus latus, Smith.

Op. cit., part i, p. 574 (280), 1873.

From the surface :

6181. Vineyard Sound, Massachusetts, U. S. Fish Commission, July 1, 1871; 1 specimen. (Type of S. I. Smith.)

This species is known only from the type specimen of Professor Smith. 


\section{Argulus megalops, Smith.}

Op. cit., part i, p. 575 (281), 1873.

From the common Skate, Raia erinacea, Mitch. :

6068. Vineyard Sound, Massachusetts, U. S. Fish Commissiou, August 28, $1883 ; 5$ specimens.

From the Sculpin, Cottus octodecimspinosus, Mitch.:

8281. Wood's Holl, Mass., V. N. Edwards, November 20, 1883; 2 specimens.

From the Web-fingered Sea robin, Prionotus palmipes, Storer:

8255, 8639. Wood's Holl, Massachusetts, U. S. Fish Commission, August, 1884 ; $5+2$ specimens.

From the common Flounder, Paralichthys dentatus, (L.) Jordan \& Gilbert:

6067. Vineyard Sound, Massachusetts, U. S. Fish Cummission, Angust 28, $1883 ; 1$ specimen.

8638. Wood's Holl, Mass., U. S. Fish Commission, September 8, 1884; 3 speeimens. (Also from Pleuronectes americanus.)

From the Spotted Sand Flounder, Bothus maculatus, (Mitch.) Jor. \& Gilb. :

6069. Vineyard Sound, Massachusetts, U. S. Fish Commission, August 28, $1883 ; 1$ specimen.

From the New England Flat Fish, Pleuronectes americanus, Walb.:

8276. Wood's Holl, Mass., V. N. Edwards, October 31, 1883 ; 2 specimens.

From the Tomcod, Microgadus tomcod, (Walb.) Gill.:

8280. Wood's Holl, Mass., V. N. Edwards, November 16, 1883; 1 specimen.

From the surface.

6179. Vineyard Sound, Massachusetts, U. S. Fish Commission, July 8, 1871 ;

3 specimens. (Types of S. I. Smith.)

From the above list it will be observed that this species occurs on many kinds of fish on the Southern New England coast. The colors vary from a nearly pure white to a yellowish white and light brownish yellow. Nearly all the specimens recently collected are considerably larger than the types of Professor Smith. The largest are (6068) from Raia erinacea and (8276) from Pleuronectes americanus. The extreme length of the largest specimen is over 5 millimeters, and the extreme brearth about 3 miliimeters.

i Argulus alosæ, Gould. Rept. Invert. of Mass., p. 340, fig., 1841 ; Smith, op. cit., part i, p. 575 ( 281$)$,
1873.

Host unknown.

4410. Great Egg Harbor, New Jersey, William Stimpson; 1 q specimen.

The single specimen above recorded was collected by the late Dr. William Stimpson, probably about twenty years ago, but the species of fish from which it was taken is not stated on the label; it may possibly 
have been captured at the surface. It agrees quite closely with the crude figure and brief description of Gould, and the species of fish (the Alewife, Clupea vernalis or astivalis Mitch.) from which his specimen was obtained occurs on the New Jersey coast. The writer has never seen specimens collected from the Alewife.

Mr. J. F. Whiteaves records this species doubtfully from the Gulf of Saint Lawrence, in the following terms: "An Argulus, closely allied to A. alose of Gould, if not identical with it, was taken off Pictou Island, in towing nets, attached to Gasterosteus biaculeatus? and other small fishes."* Prof. S. I. Smith, who has examined one of Mr. Whiteaves' specimens, regards it as probably Argulus alosa.

\section{CALIGINA.}

Caligus curtus Müller.

Entomostraca, p. 130, pl. 21, 1785; Smith, op. cit., part i, p. 575 (281), 1873. Caligus americanus Pickering and Dana, Am. Jour. Sci., vol. xxxiv, p. 225, pl. 3-5, 1838; Dana, U. S. Expl. Expd., Crust, pl. 93.

From the Cod, Gadus morrhua, Linn :

8024. Casco Bay, Me., L. A. Lee, June 15, $1883 ; 6$ \& ㅇ specimens.

8023. Harpswell, Me., L. A. Lee, November 2,$1883 ; 1$ specimen.

8022. Harpswell, Me., L. A. Lee, November 9, 1883; 1 q specimen.

8025. Cox Ledge, latitude $41^{\circ} 11^{\prime} 30^{\prime \prime}$ N., longitude $71^{\circ} 02^{\prime}$ W., U. S. Fish Commission str. Albatross, July 25, 1884; $25+\delta$ \& specimens.

From the Hake, Phycis tenuis, (Mitch.) Dek. :

8026. Off Martha's Vineyard, Mass., U. S. Fish Commission, October 4, 1882 ; 5 ㅇ specimens.

From the Barn Door Skate, Raia lavis, Mitch.:

6162. Near Station 2091 , latitude $40^{\circ} 01^{\prime} 56^{\prime \prime}$ N., longitude $70^{\circ} 59^{\prime}$ W., 117 fath., U. S. Fish Commission, September 21,$1883 ; 1$ q specimen.

Compared with specimens (8027) from the Cod, Durham coast, England, received from the Rev. A. M. Norman.

The specimens recorded above from Raia lavis may possibly have been living upon Cod taken at the same time, as it frequently happens that when large numbers of fish are taken together by means of trawls the active parasitic forms become attached to other species than those on which they commonly live. The collection of Prof. L. A. Lee, made from the Cod in Casco Bay, Maine, from which three of the above lots were selected, contained numerous specimens collected both in the spring and fall, indicating that the species is abundant in that region. It is also commonly met with in the region about Cox Ledge, off the coast of southern New England, and would probably be found wherever Cod occur on our coast.

* On recent deep-sea dredging operations in the Gulf of Saint Lawrence; Am. Jour. Sci., vii, March, 1874 (p. 8, reprint). 
PROCEEDINGS OF UNITED STATES NATIONAL MUSEUM. 487

? Caligus productus, Dana.

U. S. Expl. Expd., Crust., vol. ii, p. 1354, pl. 94, fig. 4.

From the Dolphin, Coryphcena, sp.:

6109. Latitude $38^{\circ} 19^{\prime}: 26^{\prime \prime}$ N., longitude $68^{\circ} 20^{\prime} 20^{\prime \prime}$ W., surface, U. S. Fish Commission steamer Albatross, $18\ulcorner 3 ; 8 \hat{\sigma}$ ㅇ specimens. (Inside of gill-covers and surface of body).

Our specimens agree tolerably well with the figures given by Kröyer,* who also had it from the Dolphin; but there are some points of differ. ence which render the identification doubtful until comparison can be made with authentic specimens.

Caligus rapax, Edwards.

Hist. Nat. des Crustacés, tome iii, p. 453, pl. 38, fig. 9-12, 1840; Smith, op. cit., part i, p. 575 (281), 1873.

From the Sting Ray, Trygon centrura, (Mitch.) Gill :

6188. Vineyard Sound, Massachusetts, U. S. Fish Commission, 1871; 6 specimens.

From the surface:

6197. Vineyard Sound, Massachusetts, U. S. Fish Commission, September 3, $1871 ; 2$ \% $\&$ specimens.

The specimens here recorded are the ones originally referred to this species by Prof. S. I. Smith (loc. cit.). Numerous specimens of apparently the same species have since been obtained from many other sources, but as I have not been able to identify them satisfactorily, I prefer to omit them from the present list. They may possibly represent a new species.

Lepeophtheirus Nordmannii, (M. Edwards) Baird.

Nat. Hist. of the British Entomostraca, p. 275, pl. xxxiii, fig. 1, 1850.

From the Sunfish, Molx rotunda, Cuv.:

6018. Vineyard Sound, Massachusetts, U. S. Fish Commission, August 19, 1882 ; $30+$ q specimens.

Lepeophtheirus salmonis, Kröyer.

Naturhistorisk Tidsskrift, III, vol. ii, p. 211, pl. 17, fig. 1, 1863; Smith, op. cit., part i, p. 576 (282), 1873 ; part ii, p. 662, 1874.

From Salmon? (Salmo, sp.):

8489. Ungava Bay, Labrador, L. M. Turner, observer, U. S. Signal Service; $15+q$ specimens.

From the Gorbuscha Salmon, Oncorhynchus gorbuscha, (Walb.) Gill \& Jor.:

6107. Port Chatham, Cook's Inlet, Alaska; 2 오 specimens.

Compared with English specimens (8030) from the Salmon, received from the Rev. A. M. Norman, with which the American specimens agree closely. There are also in the National Museum collection several spec-

* Naturhistorisk Tidsskrift, ser. 3, vol. ii, p. 138, pl. 3, fig. 4, 1863-'64. 
imens (8117) of a Lepeophtheirus, taken from the King Salmon (Oncorhynchus chouicha), in Kenai, Alaska, by Mr. W. J. Fisher, July, 1880, which differ but slightly from this species, and may possibly be only a variety of it. The principal differences noticed were as to the second pair of foot-jaws; which are proportionally shorter, and are armed with an elongate crest on the front edge near the middle.

The specimens from Mr. Turner, Ungava Bay, Labrador, are not labeled as to the fish from which they were obtained, and as that observer is still absent from this country, it is impossible to more than surmise their origin. His notes will undoubtedly furnish the desired information on his return.

Echthrogaleus coleoptratus, (Guérin) Steenstrup \& Lütken.

Det Kongelige Danske Videnskabernes Selskabs Skrifter, Femte Række, Naturvidenskabelig og Mathematisk Afdeling, Femte Bind, Kjöbenhavn, p. 380, pl. 8, fig. 15, 1861; Smith, op. cit., part i, p. 576 (282), 1873.

From dorsal fin of the Mackerel Shark, Lamna cornubica, (Gmel.) Fleming:

6185. Vineyard Sound, Massachusetts, U. S. Fish Commission, September 19, $1871 ; 2$ \& specimens.

Compared with specimens (8179) from Cornwall, England, received from the Rev. A. M. Norman.

Echthrogaleus denticulatus, Smith.

Op. cit., part i, p. 576 (282), 1873.

From Atwood's Shark, Carcharodon Atwoodi, (Storer):

6196. Vineyard Sound, Massachusetts, U. S. Fish Commission, 1871; 1 q specimen. (Type of S. I. Smith.)

Professor Smith's type specimen is the only one known.

Pandarus Cranchii, Leach.

Dict. des Sci. Nat., tome xiv, p. 53i, 1819; Smith, op. cit., part i, p. 576 (282), 1873.

From the Dusky Shark, Carcharinus obscurus, (Lesueur) Jor. \& Gilb.:

6019 , 6020. Station 1142 , latitude $39^{\circ} 32^{\prime}$ N., longitude $72^{\circ}$ W., surface, U. S. Fish Commission, September 8, $1882 ; 1+3$ ㅇ specimens.

From large Shark, species undetermined:

8641. Station 2237 , latitude $39^{\circ} 12^{\prime} 17^{\prime \prime}$ N., longitude $72^{\circ} 09^{\prime} 30^{\prime \prime}$ W., surface, U.S. Fish Commission, steamer Albatross, September 13, 1884 ; 3 specimens.

Compared with specimens (6831) furnished by Prof. G. S. Brady, of England, collected by H. M. S. Challenger from Carcharias brachyurus, between Papua and Japan. Slight differences were noticed in some of the appendages, though none were apparently of specific value. 
Nogagus curticaudis, (Dana) Brady.

Report on the scientific results of the voyage of H. M. S. Challenger, vol. viii, part xxiii, report on the Copepoda, p. 135, 1883.

From the Dusky Shark, Carcharinus obscurus, (Lesueur) Jor. \& Gilb.: 6033. Station 1142 , latitude $39^{\circ} 32^{\prime}$ N., longitude $72^{\circ}$ W., surface, U. S. Fish Commission, September 8, $1882 ; 9$ o specimens.

The above specimens were identified by comparison with a specimen of Nogagus curticaudis (6917), kindly furnished by Prof. G. S. Brady, of England, and obtained by H. M. S. Challenger, on Carcharias brachyurus, between Papua and Japan. I can distinguish only slight differences between them, which could not be regarded as of specific value. Our specimens were associated with Nogagus Latreillii and Pandarus Cranchii on the same fish.

Nogagus Latreillii, Leach.

Dict. des Sci. Nat., tome xiv, p. 536, 1819, (teste Edwards et al.)

From the Dusky Shark, Carcharinus obscurus, (Lesueur) Jor. \& Gilb.: 6031. Station 1142 , latitude $39^{\circ} 32^{\prime}$ N., longitude $72^{\circ}$ W., surface, U. S. Fish Commission, September 8, 1882; 1 ơ specimen.

From large Shark, species not determined :

8640. Station 2237 , latitude $39^{\circ} 12^{\prime} 17^{\prime \prime}$ N., longitude $72^{\circ} 09^{\prime} 30^{\prime \prime}$ W., surface, U. S. Fish Commission, steamer Albatross, September 13, $1884 ; 6$ శ specimens. (Associated with Pandarus Cranchii, No. 8641.)

In addition to the above, there are in the National Museum collection many other specimens of a Nogagus, of smaller size, obtained from several species of sharks, which belong to a closely related, if not the same, species. I have omitted them from the list until they can be compared with European specimens. One lot of these, from Atwood's shark (Carcharodon Atwoodi) were recorded by Prof. S. I. Smith, in the Report of the U. S. Fish Commissioner, Part I, p. 576, as Nogagus Latreillii, and in the same connection that author mentions the principal differences from the published figures and descriptions, which I have also observed.

Cecrops Latreillii, Leach.

Encyl. Brit., Suppl., vol. i, p. 405, pl. 20, 1816, (teste M. Edwards et al.); Gould, Rept. Invert. Mass., p. 341, 1841; Smith, op. cit., part i, p. 577 (283), 1873.

From the Sunfish, Mola rotunda, Cuv.:

6017. Off Gay Head, Massachusetts, U. S. Fish Commission, July 12, 1881; 2。ㅇ specimens. (Gill laminæ.)

Læmargus muricatus, Kröyer.

Naturhistorisk Tidsskrift, bind i, p. 487, pl.5, fig. A, B, C, D., 1837.

Host unknown.

3693. Jeffrey's Bank, Gulf of Maine, fishing schooner Paul Revere; 2 요 specimens. (Gloucester Donation No. 926.) 


\section{DICHELESTINA.}

Dichelestium sturionis, Hermann.

Mém. aptérologique, p. 125, pl. 5, figs. 7, 8, 1804, (teste M. Edwards); M. Edwards, Iist. Nat. des Crust., vol. iii, p. 485, pl. 39, fig. 4, 1840; Van Beneden, Aunales des Sciences Naturelles, III, Zool., tome 16, p. 95, 1851.

From the Sturgeon, Acipenser oxyrhynchus, Mitch.:

6189. Vineyard Sound, Massachusetts, U. S. Fish Commission, $1875 ; 1$ o specimen.

8184. Vineyard Sound, Massachusetts, U. S. Fish Commission, 1884; 1 우 specimen. (Inside of gill-covers.)

6173. Fisher's Island Sound, Connecticut, U. S. Fish Commission, July 20, $1874 ; 20+\delta$ \& specimens. (Gill cavity.)

6175. Long Island Sound, off Noank, Connecticut, U. S. Fish Commission, July 22,$1874 ; 2$ f $\&$ specimens. (Gill cavity.)

6174. Long Island Sound, off Noauk, Connecticnt, U. S. Fish Commission, August 20,1874; $8+\hat{\delta}$ ㅇ specimens. (Long-nosed Sturgeon.)

Compared with specimens (8185) from the Sturgeon, Cornwall, England, received from the Rev. A. M. Norman.

Anthosoma crassum, (Abildgaard) Steenstrup \& Liitken.

Op. cit., p. 397, pl.12, fig. 24, 1861 ; Smith, op. cit., part i, p. 577 (283), 1 ¿73.

Anthosoma Smithii, Leach; Gould, Rept. Invert. of Mass., p. 341, 1841.

From the Sand Shark, Odontaspis littoralis, (Mitch.) Jor \& Gilb. :

6039. Vineyard Sound, Massachusetts, U. S. Fish Commission, August 7, $1883 ; 1$ o specimen. (Fin.)

From the Spiny Dog-fish, Squalus acanthias, Liun.:

8034. About 125 miles sot:th of Marth:t's Vineyard, Massachusetts, U. S. Fish Commission, steamer Albatross, Angust 5, 1884; 1 of specimen.

Compared with a specimen (8108) from England, obtained from Lamna cornubica by Dr. Francis Day.

\section{CHONDRACANTHINA.}

Anteacheres Dübenii, M. Sars.

Nyt Magazin for Naturvidenskaberne, p. 128, pl. 9, fig. 24-34, pl. 10, fig. 3553,1870 .

From the deep-water Actinian, Bolocera Tuedice, Gosse :

6009. Station 879 , latitude $39^{\circ} 49^{\prime} 30^{\prime \prime}$ N., longitude $70^{\circ} 54^{\prime}$ W., 225 fathoms, September 13, 1880, U. S. Fish Commission; 26 $\delta$ specimens.

6010. Same station; 8 o $\&$ specimens.

6011,6012 . Same station ; $11+15$ \& specimens.

6004. Station 1112 , latitude $39^{\circ} 56^{\prime}$ N., longitude $70^{\circ} 35^{\prime}$ W., 245 fathoms, August 22, 1882, U. S. Fish Commission ; 8 o $q$ specimens.

6003. Station 1153 , latitude $39^{\circ} 54^{\prime}$ N., longitude $70^{\circ} 37^{\prime}$ W., 225 fathoms,

October 4, 1882, U. S. Fish Commission ; 28 o specimens.

6005. Same station; 2 o ㅇ specimens.

$6006,6007,6008$. Same station ; $6+3+11$ q specimens.

This species is generally abundant wherever Bolocera Tuedice occurs ; it lives in the stomach and body cavity. Several specimens are often obtained from a single Actinian. 


\section{LERN AEOPODINA.}

Lernæopocin (?) coregoni, Smith.

Op. cit., part ii, p. 664, pl. iii, fig. 17, 1874.

From the Whitefish, Coregonus clupeiformis, (Mitch.) Milner:

6072. Grand Island, Lake Superior, J. W. Milner ; 1 \& specimen.

Brachiella rostrata, Kröyer.

Naturhistorisk Tidsskrift, bind i, p. 207, pl. 2, fig. 1, 1837.

From the Halibut, Hippoglossus vulgaris, Fleming :

6212. Fishing grounds of Eastern North America, Gloucester fishing vessel, $1883 ; 4$ ㅇ specimens. (The exact locality not known.)

Compared with specimens (8343) from the halibut, Shetland, received from the Rev. A. M. Norman.

Anchorella uncinata, (Müller) Nordmann.

Mikrographische Beiträge, Zweites Heft, p. 102, pl. 8, fig. 8-12, pl. 10, fig. $1-5,1832$; Smith, op. cit., part i, p. $578(284) 1873$.

From the Cod, Gadus morrhua, Linn.:

7997. Casco Bay, Maine, L. A. Lee, 1883; 3 ९ specimens. (Fins and gills.)

7996. Harpswell, Me., L.A. Lee, October 6,$1883 ; 5$ specimens. (Gills and fins.)

7994. Harpswell, Me., L. A. Lee, October 27, 1883; 1 \& specimen. (Fins.)

7993. Harpswell, Me., L. A. Lee, November 2,1883 ; 2 ㅇ specimens.

7995. Harpswell, Me., L. A. Lee, November, 1883; 2 \& specimens. (Fins and gills.)

6140. Off the southern coast of New England, U. S. Fish Commission, 1883 ;

1 o specimen. (Side of month.)

7990. Cox Lerlge (latitude $41^{\circ} 11^{\prime} 30^{\prime \prime}$ N., longitude $71^{\circ} 02^{\prime}$ W.), U. S. Fish Commission, steamer Albatross, July, 1884; 30+ + specimens. (Gills and inside of gill-covers.)

8347. Cox Ledge, U. S. Fish Commission, steamer Albatross, August 1, 1884 ; $10+\uparrow$ specimens. (Gills and fins.)

7991. Bering Island, Siberia, L. Stejneger (2422), 1882-'83; 1 \& specimen.

7992. Bering Island, Siberia, L. Stejneger (2423), 1882-'83; 6 ㅇ specimens.

From the Haddock, Melanogrammus aglefinus, (Linn.) Gill :

6118. George's Bank, U. S. Fish Commission, steamer Albatross, August 22, $1883 ; 4$ \& specimens. (Gills.)

Compared with specimens (7998) from Cornwall, England, received from the Rev. A. M. Norman. The specimens obtained at Bering Island, Siberia, by Mr. Stejneger, do not difier in any essential particulars from those taken on our eastern coast; but several of his specimens are much above the average size. The remarks made with regard to the distribution of Caligus curtus will apply equally well to this species.

\section{LERN AINA.}

Lernæonema radiata, (Lesueur) Steenstrup \& Lütken.

Op. cit., p. 400, 1861; Smith, op. cil., part i, p. 578 (284), pl. 7, fig. 30, 1873.

Lernoocera radiata, Lesueur, Jour. Acad. Nat. Sci., Phila., vol. iii, p. 288, pl. 11, fig. 1, 1824 .

From the Menhaden, Brevoortia tyrannus, (Latrobe) Goode:

6176. Vineyard Sound, Massachusetts, U. S. Fish Commission, 1875; 1 \& specimen. 
6002. Vineyard Sound, Massachusetts, V. N. Edwards, May 22, 1883; 8 q specimens.

6001. Vineyard Sound, Massachusetts, V. N. Edwards, July 4, 1883; 1 ㅇ specimen.

6057. Vineyard Sound, Massachusetts, U. S. Fish Commission, August 21, $1883 ; 1$ \& specimen.

6061, 6062, 6063. Vineyard Sound, Massachusetts, U. S. Fish Commission, August 23, 1883; $1+1+3$ 우 specimens.

8282. Vineyard Sound, Massachusetts, U. S. Fish Commission, 1883; 4 \% specimens.

6000. Great Egg Harbor, New Jersey, William Stimpson; 10 q specimens. (Old collection; host not recorded, but probably from Menhaden).

Prof. S. I. Simith (loc. cit.) records this species from Menhaden taken at Great Egg Harbor, New Jersey, and Stimpson's specimens abore mentioned were undoubtedly obtained from the same fish, although their origin is not stated on the label attached to them. It can scarcely be regarded as an abundant species, at least not at all seasous, and the specimens entered in the above list as from Vineyard Sound were only obtained after an examination of many hundred fish.

Lernæa branchialis, Linn.

Systema Naturæ; Steenstrup \& Liitkeu, op. cit., p. 403, pl. 13, fig. 28, (var. sigmoidea, p. 404, pl. 13, Fig. 29), 1861; Smith, op. cit., part i, p. 578 (284), 1873.

From the gills of the Cod, Gadus morrhua. Linn.:

6145. George's Bank, Captain Gourville, schooner Rebecea Bartlett, March, $1880 ; 2$ ㅇ specimens. (Gloucester donation 643.)

8488. Harpswell, Me., L. A. Lee, October 6, $1883 ; 1$ \& specimen.

6211. Disco Bay, Greenland, Ensign H. G. Dresel, U. S. N., U. S. S. Yantic, $1883 ; 2$ 오 specimens.

The majority of the specimens in the collection approach more nearly the var. sigmoidea, Steenstrup \& Liitken, than the typical form as commonly figured.

Lernæolophus sultanus, (Nordmann) Heller.

Reise der Esterreichischen Fregatte Novara um die Erile, in den Jahren 1857, 1858, 1859; Crustaceen, p. 251, pl. 25, fig. 7, 1868.

From the orange File-fish, Alutera Schœpffi, (Walb.) Goode:

6186. Vineyard Sound, Massachusetts, U. S. Fish Commission, 1874; 4 의 specimens.

Agrees quite closely with the figure given by Heller, except that the appendages about the mouth are not so distinctly uncinate.

Hæmobaphes cyclopterina, (Fabr) Steenstrup \& Liitken.

Op. cit., p. 405, pl. 13, fig. 30, 1861.

From Lycodes Verrillii, Goode \& Bean :

6137. South of Seal Island, Nova Scotia, U. S. Fish Commission, 1877; 1 q specimen.

The single specimen in the collection is not in a sufficiently perfect condition to permit of a careful examination of the mouth parts, but in all other details it agrees quite well with the figures of Steenstrup and Liitken. 


\section{$2 \mathrm{BHL}$ Biodiversity Heritage Library}

Rathbun, Richard. 1885. "Annotated list of the described species of parasitic Copepoda (Siphonostoma) from American waters contained in the United States National Museum." Proceedings of the United States National Museum 7(454), 483-492. https://doi.org/10.5479/si.00963801.454.483.

View This Item Online: https://www.biodiversitylibrary.org/item/31798

DOI: https://doi.org/10.5479/si.00963801.454.483

Permalink: https://www.biodiversitylibrary.org/partpdf/11584

\section{Holding Institution}

Smithsonian Libraries

\section{Sponsored by}

Smithsonian

\section{Copyright \& Reuse}

Copyright Status: NOT_IN_COPYRIGHT

This document was created from content at the Biodiversity Heritage Library, the world's largest open access digital library for biodiversity literature and archives. Visit BHL at https://www.biodiversitylibrary.org. 